\title{
STUDI MOLECULAR DOCKING SENYAWA GOLONGAN FLAVONOL SEBAGAI ANTIBAKTERI
}

\author{
Isna Wardaniati ${ }^{1)}$ Muhammad Azhari Herli ${ }^{2)}$ \\ 1) Analis Farmasi dan Makanan, Universitas Abdurrab Jl. Riau Ujung No.73 \\ email : isna.wardaniati@univrab.ac.id \\ 2) Analis Farmasi dan Makanan, Universitas Abdurrab J1. Riau Ujung No.73 \\ email : azhari.herli@univrab.ac.id
}

\begin{abstract}
In this paper we studied the bioactive compounds of Flavonol-D-alanil D-alanin dekarboksipeptidase receptor interactions In silico. First, prepared three dimensional structure of D-alanil D-alanin dekarboksipeptidase as receptor. Preparation of fourth bioactive compounds of flavonol which will be as ligands, klokasilin and D-alanil D-alanin as a comparison. The fourth bioactive compounds of flavonol, klokasilin and D-alanil D-alanin were docked with D-alanil Dalanin dekarboksipeptidase until energy values were obtained. The fourth bioactive compounds of flavonol had lesser binding energy values than D-alanil D-alanin, Quercitrine and rutin also predicted to have greater binding energy and
\end{abstract} binding affinity than klokasilin (antibiotic) and D-alanil D-alanin (nature ligand).

\section{Keywords}

Molecular Docking, Flavonol, Antibacterial, D-alanil D-alanin dekarboksipeptidase receptor

\section{Pendahuluan}

Peningkatan penyakit yang disebabkan infeksi mikroorganisme patogen telah meningkat di seluruh dunia dan menyebabkan peningkatan mortalitas terutama di negara berkembang. Peningkatan penyakit infeksi ini salah satunya disebakan karena penggunaan antibiotik yang tidak tepat sehingga menyebabkan meningkatnya resistensi mikroorganisme patogen tersebut [1].

Salah satu upaya penemuan obat baru untuk mengobati infeksi yang disebabkan mikroorganisme adalah dengan penapisan senyawa bioaktif yang berasal dari alam. Flavonoid merupakan salah senyawa bioaktif alami yang memiliki berbagai khasiat dalam pengobatan seperti sebagai antibakteri [2], antijamur, antivirus [3], antioksidan [4] [5], antiinflamasi, antialergi, aktivitas sebagai cardiotonic [3] dan antitumor. Senyawa bioaktif yang terdapat di flavonoid yang memiliki aktivitas sebagai antibakteri seperti (+) katekin, rutin [6], kuersetin [3], kuersitrin , kaempferol, dan luteolin. Beberapa penelitian telah dilakukan dan dilaporkan bahwa senyawa flavonoid diatas efektif untuk digunakan sebagai antibakteri pada bakteri yang telah resisten [7]. Penelitian ini untuk mempelajari interaksi senyawa bioaktif flavonoid dengan target $D$-alanil D-alanin dekarboksipeptidase yang dilakukan dengan bantuan aplikasi perangkat lunak dari komputer (in silico). Metode in silico ini lazim digunakan dalam proses penapisan awal senyawa bioaktif untuk kandidat obat. Hal ini disebabkan melalui pendekatan in silico terjadi interaksi senyawa bioaktif dengan protein target [8]. Untuk mengetahui besarnya interaksi senyawa bioaktif dengan target dilakukan dengan pendekatan penambatan molekul (molecular docking). Penambatan molekul (Molecular Docking) sebagai proses penapisan awal antara molekul senyawa bioaktif yang berikatan dengan sisi aktif $D$-alanil $D$-alanin dekarboksipeptidase. Penambatan molekul adalah salah satu metode untuk penapisan senyawa dengan prinsip berdasarkan struktur (structure based) dengan bantuan komputasi. Selama proses pengikatan antara protein dan ligan, terdapat perubahan entalpi dan entropi dalam sistem protein-ligan yang 
berkaitan dengan struktur antara protein dan ligan. Metode komputasi (in silico) ini memprediksi interaksi dan afinitas ikatan serta konformasi dari kompleks senyawa protein-ligan tersebut [9]. Metode in silico banyak digunakan pada penelitian awal dalam penemuan senyawa antikanker [10], antivirus [8] [10] dan penemuan senyawa bioaktif yang dapat digunakan sebagai kandidat obat [11].

\subsection{Perumusan Masalah}

Dari penelusuran literatur yang telah dilakukan, belum ada dilakukan penelitian mengenai penambatan molekul (molecular docking) senyawa bioaktif flavonoid golongan flavonol (kuersetin, kuersitrin, kaempferol dan rutin) terhadap target $D$-alanil D-alanin dekarboksipeptidase. Informasi mengenai penambatan molekul dibutuhkan untuk mengetahui potensi senyawa bioaktif flavonoid untuk menjadi obat/inhibitor.

Berikut adalah permasalahan penelitian ini :

1. Bagaimana hasil penambatan molekul senyawa bioaktif flavonoid di sisi aktif protein target $D$-alanil D-alanin dekarboksipeptidase yang relatif lebih cocok menggunakan software Autodock Vina?

2. Bagaimana interaksi yang terbentuk antara molekul senyawa bioaktif flavonoid di sisi aktif protein target $D$-alanil D-alanin dekarboksipeptidase hasil penambatan molekul (molecular docking)?.

\subsection{Tujuan Penelitian}

Penelitian ini bertujuan untuk :

1. Penambatan molekul antara senyawa bioaktif flavonoid golongan flavonol (kuersetin, kuersitrin, kaempferol dan rutin) dengan target $D$-alanil $D$-alanin dekarboksipeptidase yang dilakukan dengan bantuan aplikasi perangkat lunak dari komputer (in silico) dengan ligan pembanding ligan alaminya yaitu klokasilin dan $D$-alanil $D$-alanin.

2. Melihat interaksi antara senyawa bioaktif flavonoid yaitu (+) katekin, rutin, kuersetin, kuersitrin, kaempferol, dan luteolin setelah dilakukan penambatan molekulnya dengan target $D$-alanil $D$-alanin dekarboksipeptidase dengan ligan alami pembanding ligan alaminya yaitu klokasilin dan $D$-alanil $D$-alanin.

\subsection{Manfaat Penelitian}

Penelitian ini diharapkan akan dapat memberikan informasi penambatan molekul (molecular docking) senyawa bioaktif flavonoid yaitu golongan flavonol (kuersetin, kuersitrin, kaempferol dan rutin) dengan target $D$-alanil $D$ alanin dekarboksipeptidase yang dilakukan dengan bantuan aplikasi perangkat lunak dari komputer (in silico). Bagi peneliti sendiri, penelitian ini dapat menambah pengetahuan dan keterampilan dalam melakukan proses penambatan molekul (molecular docking). Rencana target capaian penelitian ini adalah publikasi jurnal farmasi dan makanan (http:Ijjm.univrab.ac.id) dan prosiding /persentasi oral pada seminar nasional.

\section{Material dan Metode Penelitian}

\subsection{Tempat dan Waktu Penelitian}

Penelitian akan dilaksanakan selama kurang lebih enam bulan (September 2016 - Februari 2017) Laboratorium Anafarma, Fakultas Kedokteran dan Ilmu Kesehatan Universitas Abdurrab.

\subsection{Material (Hardware dan Software)}

\subsubsection{Hardware}

Hardware yang akan digunakan pada penelitian ini adalah : Laptop processor I7 dengan sistem operasi Windows 1064 bit, Printer cannon.

\subsubsection{Software}

Software yang digunakan pada penelitian ini adalah :

1. Browser Mozilla Firefox versi 45.0 untuk pencarian online di Protein Data Bank (http://www.rcsb.org),

2. Software yang digunakan untuk molecular docking secara virtual molekul digunakan software Autodock vina versi 1.1.2 (didownload dari http://vina.scripps.edu/download.html) dengan antar muka windows software PyRx.

3. Software yang digunakan untuk preparasi dan visualisasi ligan (senyawa golongan flavonol) adalah MarvinSketch versi 14.0, YASARA (dapat didownload di http://www.yasara.org/downloads.htm), PyMol (versi educational didownload di http://pymol.org/edu/?q=educational/) dan Discovery studio 4.1 (free software didownload di http://accelrys.com/resource-center/downloads/freeware/index.html). 


\subsection{Metode Penelitian}

\subsubsection{Preparasi Struktur Molekul ligan (senyawa golongan flavonol)}

Senyawa bioaktif flavonoid yaitu rutin, kuersetin, kuersetin, dan kaempferol. Struktur keempat senyawa aktif ini didownload dari PubChem database (http://pubchem.ncbi.nlm.nih.gov), dipreparasi dengan menggunakan software MarvinSketch versi 14.0 dan Discovery Studio 4.1, Setelah dipreparasi, molekul ligan disimpan dalam satu folder dengan format pdb dan format mol2 sesuai dengan namanya masing-masing.

\subsubsection{Preparasi Struktur Protein D-alanil D-alanin dekarboksipeptidase (DACA)}

Struktur protein D-alanil D-alanin dekarboksipeptidase di download dari Protein Data Bank (PDB) (http://www.rcsb.org), dengan PDB ID: 3MZD. Molekul D-alanil D-alanin dekarboksipeptidase dipreparasi dengan menggunakan software Discovery Studio 4.1, dalam preparasi molekul ini yang dilakukan adalah penghilangan gugus $\mathrm{H}_{2} \mathrm{O}$ (jika ada), pemisahan ligan alami (klokasilin) yang terdapat di $D$-alanil D-alanin dekarboksipeptidase dan penambahan atom hidrogen (biasanya file dalam format .pdb belum lengkap atom hidrogennya). Setelah dipreparasi, molekul D-alanil D-alanin dekarboksipeptidase dan ligan alami (kolokasilin) yang telah dipisahkan disimpan dalam satu folder dengan format .pdb dan format .mol2.

\subsubsection{Penentuan Sisi Aktif D-alanil D-alanin dekarboksipeptidase}

Sisi aktif $D$-alanil $D$-alanin dekarboksipeptidase merupakan tempat berikatannya ligan senyawa golongan flavonol. Pada penelitian ini pencarian sisi aktif tempat berikatan ligan dengan $D$-alanil $D$-alanin dekarboksipeptidase menggunakan software autodock vina dengan prinsip yang sama adalah dengan pencarian energi ikatan terkecil dari ikatan molekul $\mathrm{H}_{2} \mathrm{O}$ di seluruh radius molekul protein D-alanil D-alanin dekarboksipeptidase.

\subsubsection{Penambatan Molekul (molecular docking)}

Dalam penelitian ini dilakukan molecular docking keempat senyawa flavonol akan menjadi ligan dengan protein menggunakan software Autodock vina versi 1.1.2 dengan antar muka (GUI) PyRx merupakan program yang terintegrasi untuk memprediksi interaksi (pengikatan) antara ligan dengan protein dan software ini dapat menangani semua aspek dalam proses docking dari preparasi molekul guna penentuan situs aktif pengikatan yang potensial dari protein target serta prediksi model pengikatan dari ligan. Molekul ligan berikatan dengan reseptor, menghambat fungsi dari reseptor, sehingga ligan tersebut bertindak sebagai obat.

Parameter yang digunakan pada proses molecular docking dengan Autodock vina versi 1.1.2 antara lain pada RMSD (Root Mean Square Deviation) $\leq 2$ dilihat binding energy $(\mathrm{kcal} / \mathrm{mol})$ protein $D$-alanil D-alanin dekarboksipeptidase-ligan yang terkecil.

\subsubsection{Analisa Hasil Penambatan Molekul (Molecular Docking)}

Nilai/skor binding energy yang didapat dari molecular docking antara keempat senyawa flavonol dengan $D$ alanil D-alanin dekarboksipeptidase dibandingkan dengan hasil/skor binding energy molecular docking antara ligan alami yaitu D-alanil D-alanin dan antibiotika klokasilin dengan $D$-alanil D-alanin dekarboksipeptidase. Jika hasil/skor binding energy yang didapat dari keempat senyawa flavonol lebih kecil/rendah nilai binding energy dari binding energy ligan alami (D-alanil D-alanin) dan antibiotika (klokasilin), maka senyawa dapat disimpulkan bahwa keempat senyawa flavonol tersebut dapat bersaing untuk berikatan di molekul $D$-alanil $D$-alanin dekarboksipeptidase dan lebih poten.

Hasil/skor binding energy yang terbaik yang didapatkan dari hasil molecular docking ditampilkan dalam bentuk tabel dan kemudian di visualisasikan tempat berikatan dan jenis ikatan molekulnya secara 3 dimensi (3D) dengan software PyMol. 


\section{Hasil Percobaan}

Nilai binding energy yang didapat dari hasil molecular docking keempat ligan flavonol, ligan alami (D-alanil D-alanin) dan antibiotika (klokasilin) terhadap reseptor $D$-alanil D-alanin dekarboksipeptidase dapat dilihat di tabel di bawah ini :

Tabel 1 Nilai Binding Energy

\begin{tabular}{|l|c|c|c|}
\hline \multicolumn{1}{|c|}{ Ligan } & Reseptor Target & Binding energy (kcal/mol) & Nilai RMSD \\
\hline Kaempferol & D-alanil D-alanin dekarboksipeptidase & $\mathbf{- 7 . 5}$ & $<2$ \\
\hline Kuersetin & D-alanil D-alanin dekarboksipeptidase & $\mathbf{- 7 . 8}$ & $<2$ \\
\hline Kuersitrin & D-alanil D-alanin dekarboksipeptidase & $\mathbf{- 8 . 7}$ & $<2$ \\
\hline Rutin & D-alanil D-alanin dekarboksipeptidase & $\mathbf{- 8 . 4}$ & $<2$ \\
\hline $\begin{array}{l}\text { D-alanil D- } \\
\text { alanin }\end{array}$ & D-alanil D-alanin dekarboksipeptidase & $\mathbf{- 5 . 4}$ & $<2$ \\
\hline Klokasilin & D-alanil D-alanin dekarboksipeptidase & $\mathbf{- 8 . 1}$ & $<2$ \\
\hline
\end{tabular}

Dari tabel 1 diatas terlihat binding energy keempat senyawa flavonol lebih rendah dibandingkan ligan alami (Dalanil D-alanin) dan hanya kuersetin dan rutin yang memiliki binding energy -8,7 dan -8,4 lebih kecil dari klokasilin (8,1) yang merupakan antibiotika pembanding. Binding energy hasil docking ligan-ligan diatas pada RMSD $<2$ Amstrong. RMSD (Root Mean Square Deviation) dari heavy atom senyawa hasil docking diterima jika kurang atau sama dengan 2 angstrom, RMSD merupakan perbandingan nilai sudut molekul ligan hasil docking dengan dengan ligan awal [12]. Berikut gambar hasil docking keempat senyawa flavonol, D-alanil D-alanin dan klokasilin.

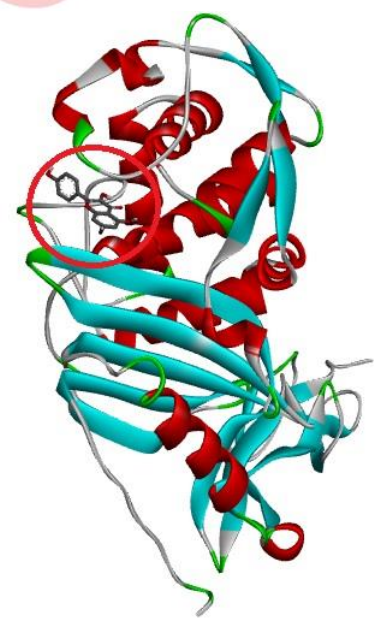

(a)

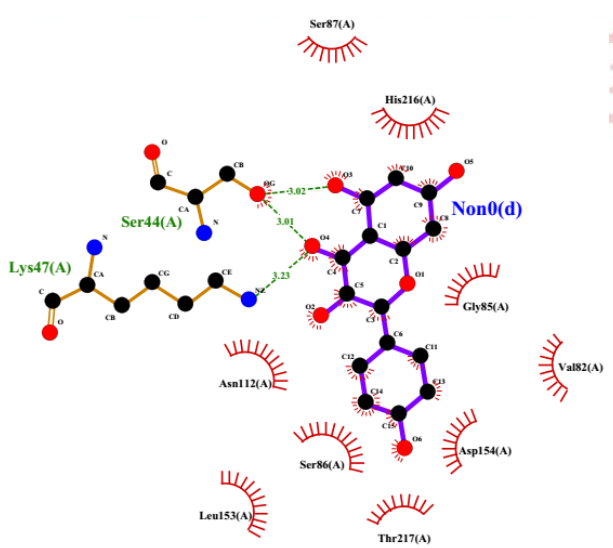

(b)

Gambar 1. a) Hasil docking kaempferol- D-alanil D-alanin dekarboksipeptidase (ligan ditunjukkan dengan lingkaran merah). b) Ikatan kaempferol dengan residu protein 


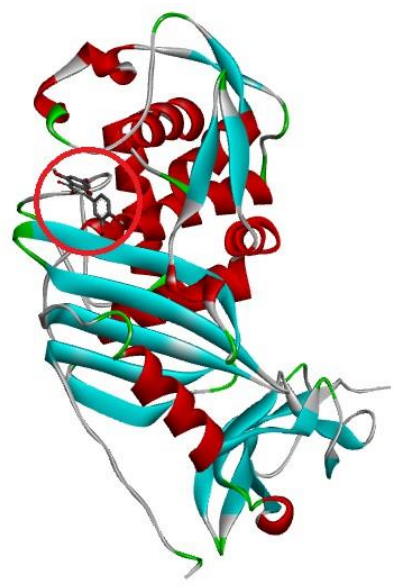

(a)

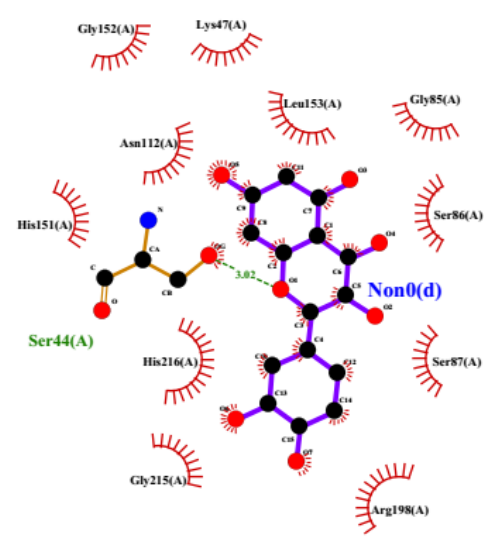

(b)

Gambar 2. a) Hasil docking kuersetin- D-alanil D-alanin dekarboksipeptidase (ligan ditunjukkan dengan lingkaran merah). b) Ikatan kuersetin dengan residu protein

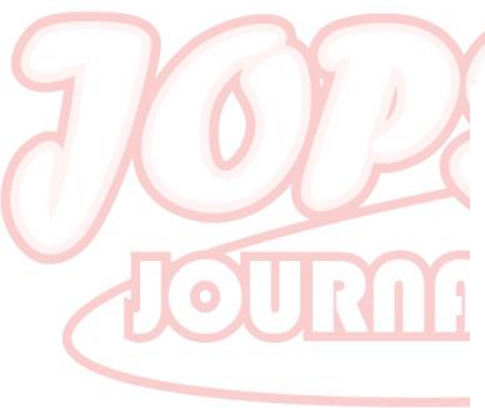

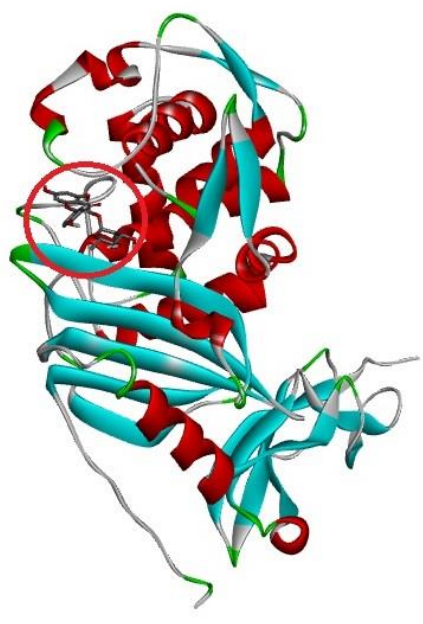

(a)

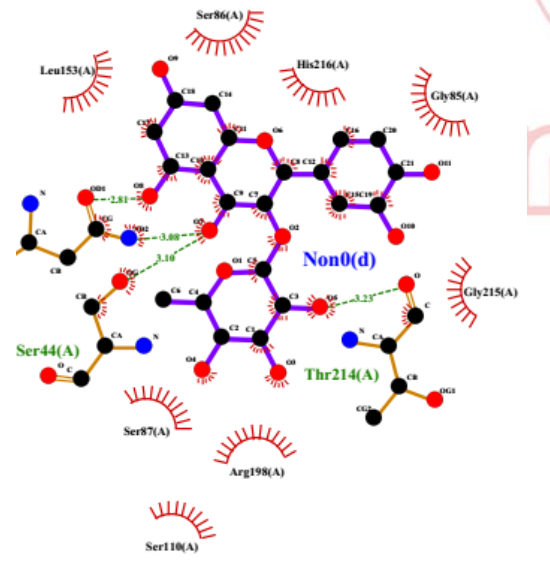

(b)

Gambar 3. a) Hasil docking kuersitrin- D-alanil D-alanin dekarboksipeptidase (ligan ditunjukkan dengan lingkaran merah). b) Ikatan kuersitrin dengan residu protein 


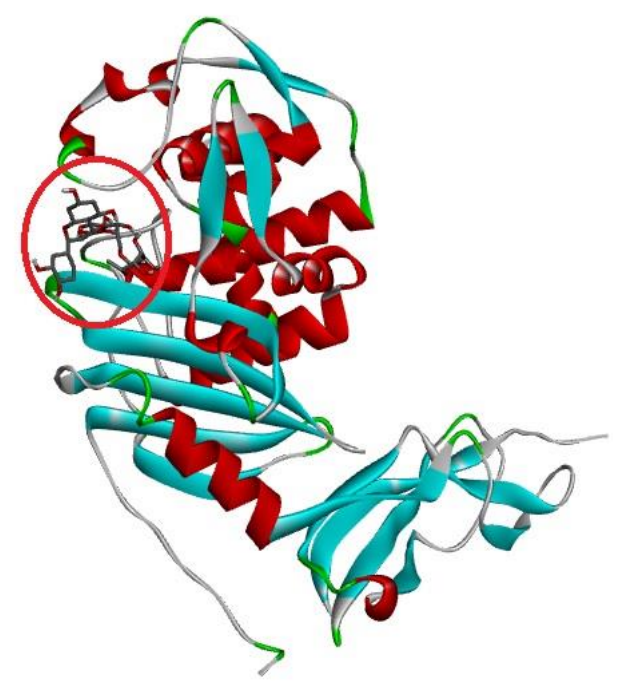

(a)

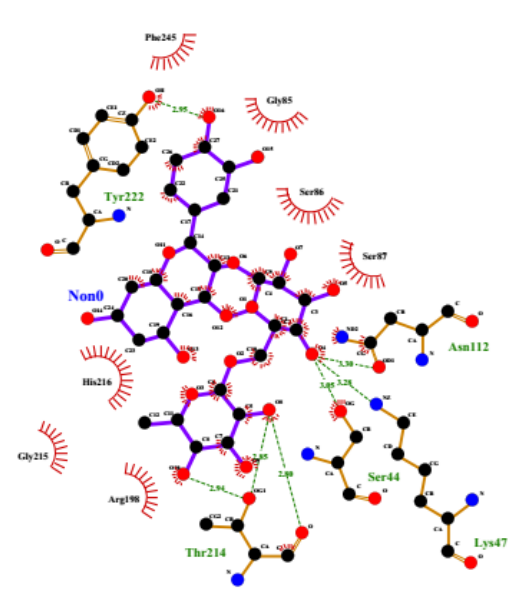

(b)

Gambar 4. a) Hasil docking rutin- D-alanil D-alanin dekarboksipeptidase (ligan ditunjukkan dengan lingkaran merah).

b) Ikatan rutin dengan residu protein

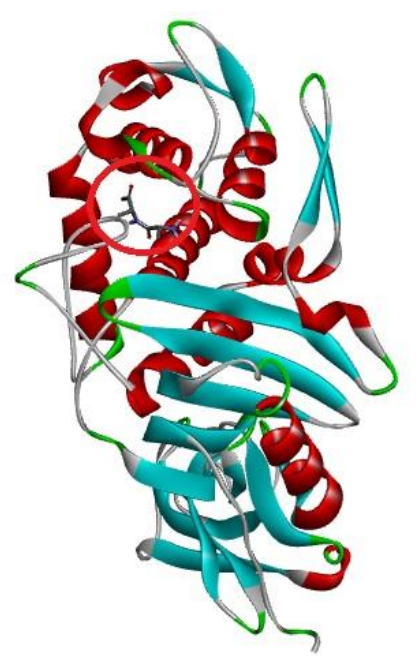

(a)

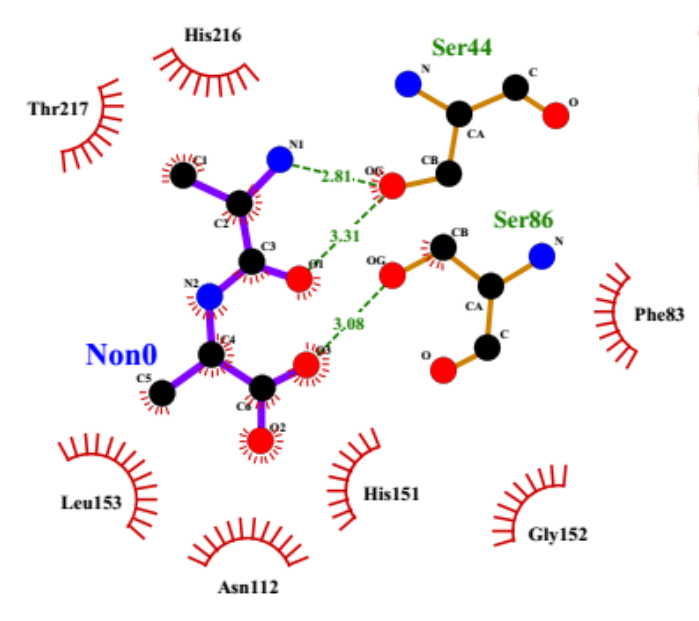

(b)

Gambar 5. a) Hasil docking $D$-alanil D-alanin - D-alanil D-alanin dekarboksipeptidase (ligan ditunjukkan dengan lingkaran merah). b) Ikatan $D$-alanil $D$-alanin dengan residu protein 


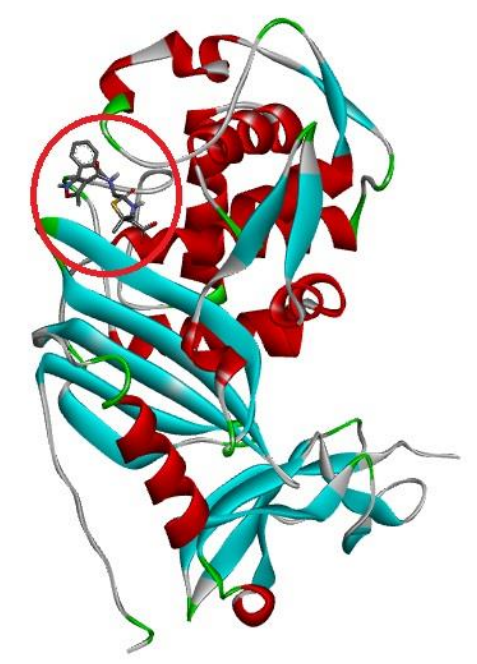

(a)

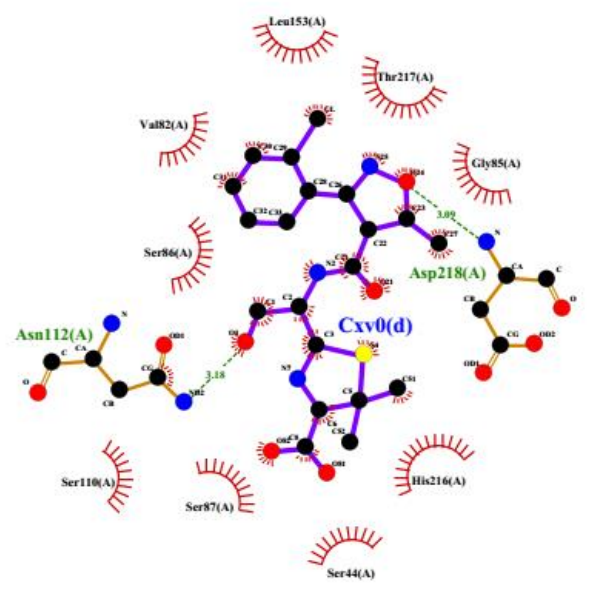

(b)

Gambar 6. a) Hasil docking klokasilin - D-alanil D-alanin dekarboksipeptidase (ligan ditunjukkan dengan lingkaran merah). b) Ikatan klokasilin dengan residu protein

\section{Kesimpulan}

Dari penelitian ini didapat bahwa binding energy keempat senyawa flavonol lebih rendah dibandingkan ligan alami (Dalanil D-alanin) dan hanya kuersitrin dan rutin yang memiliki binding energy -8,7 dan -8,4 lebih kecil dari klokasilin $(-8,1)$ pada RMSD < 2 Amstrong sehingga dapat ditarik kesimpulan bahwa senyawa kuersetin dan rutin lebih poten dibandingkan D-alanil D-alanin yang merupakan ligan alami dan klokasilin, kedua senyawa ini dapat digunakan sebagai obat antibakteri alternatif atau digunakan sebagai struktur model dalam mendisain struktur antibiotika.

\section{REFERENSI}

[1] M. A. A. Al bari, M. A. Sayeed, M. S. Rahman, and M. A. Mossadik, "Characterization and antimicrobial activities of a phenolic acid derivative produced by Streptomyces bangladeshiensis a novel specis collected in Bangladesh," 2006.

[2] J. B. Harborne and C. A. Williams, “Advances in flavonoid research since 1992," Phytochemistry, vol. 55, no. 6, pp. 481-504, 2000.

[3] A. R. Tapas, D. M. Sakarkar, and R. B. Kakde, "Flavonoids as nutraceuticals: a review," Trop. J. Pharm. Res., vol. 7, no. 3, pp. 1089-1099, 2008.

[4] T. Anggraini, A. Tai, T. Yoshino, and T. Itani, "Antioxidative activity and catechin content of four kinds of Uncaria gambir extracts from West Sumatra, Indonesia," 2011.

[5] K. E. Heim, A. R. Tagliaferro, and D. J. Bobilya, "Flavonoid antioxidants: chemistry, metabolism and structureactivity relationships," J. Nutr. Biochem., vol. 13, no. 10, pp. 572-584, 2002.

[6] D. D. Orhan, B. Özçelik, S. Özgen, and F. Ergun, "Antibacterial, antifungal, and antiviral activities of some flavonoids," Microbiol. Res., vol. 165, no. 6, pp. 496-504, 2010.

[7] T. T. Cushnie and A. J. Lamb, “Antimicrobial activity of flavonoids," Int. J. Antimicrob. Agents, vol. 26, no. 5, pp. 343-356, 2005.

[8] Fadilah, "Penapisan Senyawa Bioaktif Dari Suku Zingiberaceae Sebagai Penghambat Neuraminidase Virus Influenza A (H1n1) Melalui Pendekatan Docking,” Tesis Magister, 2010. 
[9] Rezi riadhi syahdi, "Penapisan Virtual basis data senyawa tanaman obat di Indonesia sebagai inhibitor enzim-enzim HIV-1," FMIPA Univ. Indones., 2011.

[10] D. K. Pratoko, "Molecular Docking Turunan Kalkon Terhadap Reseptor Estrogen B (Er-B) Sebagai Antikanker Payudara," 2013.

[11] D. B. Kitchen, H. Decornez, J. R. Furr, and J. Bajorath, "Docking and scoring in virtual screening for drug discovery: methods and applications," Nat. Rev. Drug Discov., vol. 3, no. 11, pp. 935-949, 2004.

[12] Hari Purnomo, Seri Penemuan Obat : Desain Molekul Antibiotika. Yogyakarta: Pustaka Pelajar, 2014.

Isna Wardaniati, Staf Pengajar program studi Diploma Analis Farmasi dan Makanan.

Muhammad Azhari Herli, Staf Pengajar program studi Diploma Analis Farmasi dan Makanan, yang mengampu mata kuliah Praktikum Mikrobiologi Farmasi I dan Mikrobiologi Farmasi II. 